\begin{tabular}{c} 
JINOP (Jurnal Inovasi Pembelajaran) \\
$\begin{array}{c}\text { P-ISSN 2443-1591 E-ISSN 2460-0873 } \\
\text { Volume 7, Nomor 1, Mei 2021, pp. 19-31 } \\
\text { http:///ejournal.umm.ac.id/index.php/jinop }\end{array}$ \\
\hline
\end{tabular}

\title{
Pengembangan media pembelajaran IPS berbasis android materi kerajaan dan peninggalan Hindu-Buddha
}

\author{
Meilia Tika Ayu Ningrum ${ }^{1)}$, Agus Purnomo ${ }^{2) *}$ Idris $^{3)}$ \\ ${ }^{1}$ Program Studi S1 Pendidikan IPS, Fakultas Ilmu Sosial, Universitas Negeri Malang, Jl. Semarang \\ No. 5, Sumbersari, Lowokwaru, Sumbersari, Malang, Indonesia \\ ${ }^{2}$ Program Studi S1 Pendidikan IPS, Fakultas Ilmu Sosial, Universitas Negeri Malang, J1. Semarang \\ No. 5, Sumbersari, Lowokwaru, Sumbersari, Malang, Indonesia \\ ${ }^{3}$ Program Studi S1 Pendidikan IPS, Fakultas Ilmu Sosial, Universitas Negeri Malang, Jl. Semarang \\ No. 5, Sumbersari, Lowokwaru, Sumbersari, Malang, Indonesia
}

meiliatika7@gmail.com; agus.purnomo.fis@um.ac.id*; idris.fis@um.ac.id

*Penulis Koresponden

\begin{tabular}{|c|}
\hline ABSTRAK \\
\hline $\begin{array}{l}\text { Media pembelajaran IPS berbasis android sebagai solusi kebosanan siswa dan mempermudah } \\
\text { siswa dalam memahami materi pembelajaran IPS. Smartphone berbasis android dipilih karena } \\
\text { dapat dikembangkan secara menarik, kreatif, inovatif, dan memudahkan siswa dalam belajar } \\
\text { mandiri. Tujuan penelitian ini untuk mengembangkan media pembelajaran IPS berbasis android } \\
\text { pada materi kerajaan dan peninggalan Hindu-Buddha dengan metode R\&D menggunakan model } \\
\text { ADDIE (Analysis, Design, Development, Implementation, Evaluation). Hasil validasi oleh ahli } \\
\text { materi dan ahli bahasa menyatakan media pembelajaran layak digunakan dengan persentase } \\
\text { berturut-turut } 61,5 \% \text { dan } 70 \% \text {. Ahli media menyatakan media sangat layak digunakan }(88,2 \%) \text {. } \\
\text { Uji coba produk menghasilkan produk sangat praktis dari praktisi pendidikan (100\%) dan }(80,2 \%) \\
\text { dari siswa. Keefektifan media terbukti efektif berdasarkan hasil belajar } 26 \text { dari } 32 \text { siswa } \\
\text { memperoleh nilai di atas KKM. Media pembelajaran IPS berbasis android dapat dikembangkan } \\
\text { oleh peneliti lain dengan memanfaatkan teknologi virtual reality. Untuk memudahkan siswa } \\
\text { dalam memahami materi pembelajaran, selain menggunakan video dan gambar, peneliti } \\
\text { selanjutnya dapat menambahkan virtual reality sehingga gambar dan objek pembelajaran dapat } \\
\text { tergambar dengan jelas. } \\
\text { Kata Kunci: Android; IPS; si-BISO Kerajaan dan Peninggalan Hindu-Buddha; Smartphone. }\end{array}$ \\
\hline ABSTRACT \\
\hline $\begin{array}{l}\text { Android-based learning media for Social Studies (SS) might reduce boredom and accelerate } \\
\text { student learning because it conveys attractive, creative, and innovative learning materials that } \\
\text { support independent learning. This study aims to develop android-based learning media for SS } \\
\text { about the Kingdom and Relics of Hindu-Buddhist. It employed Research and Development } \\
\text { (R\&D) with Analysis, Design, Development, Implementation, Evaluation (ADDIE) model. } \\
\text { Validation by material experts and linguists stated that the learning media was feasible with } \\
61.5 \% \text { and } 70 \% \text {. Results show that the learning media is suitable to use by } 88.2 \% \text {. The product } \\
\text { trials resulted in practical products by } 100 \% \text { from educational practitioners, and } 80.2 \% \text { from } \\
\text { students. This finding indicates that the media is effective, as can be seen that } 26 \text { out of } 32 \text { students } \\
\text { scored above the minimum grade. It is suggested that SS learning media are developed through } \\
\text { further research by utilizing virtual reality technology. This may accelerate student understanding } \\
\text { as the use of videos and pictures, and virtual reality to images and objects help depict things } \\
\text { clearly. } \\
\text { Keywords: Android; Social Studies; si-BISO; Hindu-Buddhist Heritage; Smartphone }\end{array}$ \\
\hline
\end{tabular}


diunggah: 2020-11-16, direvisi: 2021-03-14, diterima: 2021-04-10, dipublikasi:2021-05-20

Copyright (c) 2020 Ningrum et al

This is an open access article under the CC-BY license

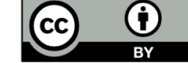

Cara sitasi: Ningrum, M.T.A., Purnomo, A., \& Idris, I. (2021). Pengembangan media pembelajaran IPS berbasis android materi kerajaan dan peninggalan Hindu-Budha. JINoP (Jurnal Inovasi Pembelajaran), 7(1), 19-31. https://doi.org/10.22219/jinop.v7i1.14344

\section{PENDAHULUAN}

Mata pelajaran IPS memiliki tujuan mendidik siswa untuk menjadi warga negara yang baik, memiliki keterampilan sosial, berakhlak mulia dan bertanggung jawab pada diri sendiri dan negara (Afandi, 2015). Dalam mencapai tujuan pembelajaran IPS tersebut, terdapat hambatan yang dihadapi oleh guru yaitu mata pelajaran IPS dianggap sebagai salah satu materi yang sulit dan membosankan bagi sebagian siswa karena banyaknya teori dan konten dalam materi IPS yang bersifat abstrak dan kompleks (Wahyuningtyas et al., 2019). Selain itu, banyaknya materi pembelajaran IPS yang menuntut banyak hafalan membuat siswa malas mengikuti proses pembelajaran IPS (Nurfajriati, 2018). Seperti pada materi kerajaan dan peninggalan pada masa Hindu-Buddha kompetensi dasar (KD) 3.4 yaitu memahami berpikir kronologi, perubahan dan kesinambungan dalam kehidupan bangsa Indonesia pada aspek politik, sosial, budaya, geografis, dan pendidikan sejak masa Pra-aksara sampai masa Hindu-Buddha dan Islam. Materi ini memiliki kompleksitas pada ranah kognitif C2 (memahami) sampai C4 (menganalisis) sehingga materi dianggap cukup luas dan sulit bagi siswa. Persoalan tersebut menghadapkan siswa pada kesulitan dalam menerima dan memahami materi pembelajaran. Di samping itu pelaksanaan proses pembelajaran IPS oleh guru menjadi salah satu penyebab siswa merasa bosan sehingga sulit memahami materi pembelajaran. Untuk itu dalam proses pembelajaran IPS perlu adanya inovasi sehingga memudahkan siswa dalam memahami materi pembelajaran.

Proses pembelajaran merupakan sebuah sistem yang terdiri dari berbagai sub-sistem yang saling terkait dan terkelola dalam komponen sistem pembelajaran (Kurniawan, 2017). Proses pembelajaran meliputi, guru, bahan ajar, media pembelajaran, siswa, dan tujuan pembelajaran yang saling mempengaruhi dalam mencapai tujuan pembelajaran. Dalam proses pembelajaran tersebut, guru membantu siswa dalam mengembangkan dan mempertahankan informasi tentang analisis tugas dan pemecahan masalah (Surahman \& Mukminan, 2017). Disisi lain, guru harus menghadapi siswa yang memiliki karakteristik gaya belajar yang berbeda-beda (Cahyani, 2014). Badlisyah dan Maghfirah (2017) menyatakan bahwa dalam proses pembelajaran, guru perlu menyesuaikan cara memberikan pembelajaran dengan karakter belajar siswa. Terdapat 3 macam karakteristik gaya belajar siswa yaitu, gaya belajar visual, gaya belajar auditorial, dan gaya belajar kinestetik (Widayanti, 2013). Gaya belajar merupakan cara termudah bagi individu dalam menyerap, mengatur dan mengolah informasi yang diterima. Disisi lain guru dapat merancang dan menciptakan sumber belajar lain sebagai penghubung pesan oleh guru kepada siswa yaitu merancang media pembelajaran dengan memanfaatkan teknologi.

Perkembangan zaman serta ilmu pengetahuan dan teknologi yang begitu pesat berpengaruh terhadap perkembangan dunia pendidikan. Kemajuan tersebut mengharuskan guru untuk mengadakan transformasi kultural (Wahyuningtyas et 
al., 2019). Transformasi dapat dilakukan oleh guru dengan memanfaatkan teknologi informasi dan komunikasi sebagai media pembelajaran jarak jauh yaitu smartphone. Media mempunyai peran penting dalam proses pembelajaran untuk membuat siswa aktif dalam proses pembelajaran, membangkitkan motivasi belajar dan meningkatkan hasil belajar (Hayati et al., 2015; Widiastika et al., 2020). Pemanfaatan media pembelajaran smartphone masih jarang dilakukan, terlebih di SMP Shalahuddin Malang. Berdasarkan hasil observasi di SMP Shalahuddin Malang, bahwa dalam proses pembelajaran khususnya IPS, masih banyak guru yang belum memanfaatkan teknologi informasi dan komunikasi sebagai media pembelajaran jarak jauh. Padahal SMP Shalahuddin Malang memperbolehkan siswa untuk membawa smartphone ke sekolah ditambah dengan menyediakan fasilitas wifi di lingkungan sekolah. Akan tetapi pemanfaatan smartphone dalam proses pembelajaran belum dilaksanakan dengan maksimal, sehingga siswa harus mengumpulkan smartphone ke wali kelas saat proses pembelajaran berlangsung. Hal ini sesuai dengan pendapat Dewi (2019) bahwa penggunaan smartphone di kalangan pelajar masih minim dimanfaatkan sebagai media pembelajaran. Untuk mendekatkan dunia siswa dalam proses pembelajaran peneliti memilih smartphone berbasis android sebagai media pembelajaran IPS karena dapat menggali potensi siswa ke arah yang edukatif dan produktif (Kurniawan et al., 2019).

Dari ulasan beberapa penelitian sebelumnya dan masalah yang ada, perlu dilakukan penelitian ini dikarenakan belum banyak dilakukan penelitian tentang pengembangan media pembelajaran berbasis android tentang materi kerjaan dan peninggalan Hindu Budha. Tujuan penelitian ini adalah mengevaluasi pemanfaatan smartphone sebagai media pembelajaran IPS berbasis android pada materi kerajaan dan peninggalan Hindu-Buddha melalui si-BISO. Smartphone dipilih sebagai media pembelajaran karena memiliki keunggulan pada aspek mobilitas dan fleksibilitas (Ismanto et al., 2017), sehingga pembelajaran antara guru dan siswa akan lebih interaktif (Maknuni, 2020). Siswa dapat mengakses materi pembelajaran dengan tampilan materi yang lebih menarik, dan interaktif (Verawati et al., 2019), sehingga siswa dapat dengan mudah belajar secara mandiri sesuai gaya belajarnya (Yuniati et al, 2017). Kelebihan-kelebihan yang dimiliki smartphone sebagai media pembelajaran tersebut, diharapkan dapat mengatasi kesulitan siswa dalam memahami materi pembelajaran IPS. Riset terdahulu menjelaskan bahwa implementasi perangkat digital dalam pembelajaran akan memberikan ragam sumber belajar tambahan yang bisa diakses oleh siswa dengan mudah serta memberikan respons yang positif (Rustandi et al., 2020). Dengan adanya media pembelajaran IPS berbasis android ini, diharapkan mempermudah pencapaian tujuan pembelajaran khususnya pada materi Peninggalan masyarakat HinduBuddha pada jenjang SMP/MTs yang menjadi fokus pengembangan. Prototipe produk ini dapat dimanfaatkan sebagai solusi siswa yang kesulitan dalam memahami pembelajaran IPS baik dengan desain terbimbing atau mandiri.

\section{METODE}

Penelitian ini menggunakan metode Research and development. Research and development merupakan metode penelitian dengan tujuan menghasilkan suatu produk dan menguji keefektifan produk tersebut (Sugiyono, 2017). Penelitian dan pengembangan ini menggunakan model ADDIE (analysis, design, development, implementation, evaluation) dengan tahap-tahap sebagai berikut: a) Tahap analysis meliputi: analisis data (analisis kurikulum dan materi, analisis kebutuhan pengguna, 
dan analisis isi program); b) Tahap design, meliputi: perancangan data dan navigasi, serta perancangan user interface; c) Tahap development meliputi: validasi ahli materi, ahli bahasa, dan ahli media; d) Tahap implementation meliputi: uji coba produk media pembelajaran dalam proses pembelajaran; e) Tahap evaluation meliputi: saran dan komentar dari validator dan pengguna produk media pembelajaran.

Subjek uji coba media pembelajaran IPS berbasis android adalah 32 siswa kelas VII A SMP Shalahuddin Malang. Teknik pengumpulan data dilakukan dengan menggunakan angket dan tes. Angket digunakan untuk validasi media pembelajaran dengan ahli materi, ahli bahasa, dan ahli media. Kepraktisan media pembelajaran diperoleh dari respons pengguna sedangkan tes digunakan untuk mengukur keberhasilan siswa dalam memahami materi dengan menggunakan media pembelajaran IPS berbasis android.

Data angket kelayakan media dianalisis dengan menggunakan rumus sebagai berikut (1):

$\mathrm{P}=\frac{\Sigma x}{\Sigma x i} \mathrm{X} 100$

Keterangan:

$\mathrm{p}:$ persentase yang dicari

$\mathrm{x}$ : jumlah keseluruhan skor jawaban

xi : jumlah skor ideal keseluruhan

Hasil skor yang telah diperoleh dapat dimasukkan ke bentuk kualifikasi penilaian (Arikunto, 2013), sebagai berikut (Tabel 1):

Tabel 1. Kriteria Analisis Produk

\begin{tabular}{lll}
\hline Persentase & Kriteria & Keterangan \\
\hline $80 \%-100 \%$ & Sangat Layak & Tidak Revisi \\
$60 \%-79 \%$ & Layak & Tidak Revisi \\
$40 \%-59 \%$ & Cukup Layak & Revisi \\
$0 \%-39 \%$ & Tidak Layak & Revisi \\
\hline
\end{tabular}

Media pembelajaran dapat dikatakan layak apabila media memperoleh skor lebih dari $60 \%$, apabila skor kurang dari $60 \%$ maka media harus direvisi dan divalidasi kembali.

Data kepraktisan pengguna media pembelajaran dianalisis dengan rumus yang diadaptasi dari (Akbar, et al., 2011) pada rumus (2):

$V p=\frac{T S E p}{S-\max } \times 100 \%$

Keterangan:

Vp : Validitas Kepraktisan

TSEp : Total Skor Empirik Kepraktisan

S-max : Skor maksimal

Berdasarkan hasil tersebut dapat diketahui kriteria kepraktisan media pembelajaran yang dapat terlihat pada tabel 2 .

Tabel 2. Kriteria Kepraktisan Media

\begin{tabular}{lll}
\hline Kriteria & Kategori & Keterangan \\
\hline $75,01 \%-100 \%$ & Sangat Praktis & Dapat digunakan tanpa revisi \\
$50,01 \%-75 \%$ & Praktis & Dapat digunakan dengan revisi \\
$25,01 \%-50 \%$ & kecil \\
$0 \%-25 \%$ & Tidak Praktis & Disarankan untuk tidak digunakan \\
\hline
\end{tabular}


Media pembelajaran dapat dikatakan praktis apabila media memperoleh skor lebih dari 50\%, apabila skor kurang dari 50\% maka media harus direvisi dan divalidasi kembali. Terakhir yaitu mengolah data ketuntasan hasil belajar siswa, dianalisis menggunakan rumus Persentase Ketuntasan Peserta Didik (3):

$\frac{\text { Jumlah Siswa yang Mencapai KKM }}{\text { Jumlah Total Siswa }} \times 100$

Hasil skor yang telah diperoleh selanjutnya dapat dimasukkan sesuai kriteria keefektifan hasil belajar setelah menggunakan media (Tabel 3):

\section{Tabel 3. Kriteria Tingkat Keberhasilan Hasil Tes Hasil Belajar}

\begin{tabular}{lll}
\hline Kategori & Rentangan Persentase & Kualifikasi \\
\hline A & $80-100$ & Sangat Efektif \\
B & $60-79$ & Efektif \\
C & $40-59$ & Kurang Efektif \\
D & $<40$ & Tidak Efektif \\
\hline
\end{tabular}

Jumlah keseluruhan tes belajar siswa dari uji coba lapangan harus lebih dari $60 \%$, jika hasil tersebut terlampaui maka, media pembelajaran dapat digunakan pada proses pembelajaran Ilmu Pengetahuan Sosial khususnya di SMP Shalahuddin Malang.

\section{HASIL DAN PEMBAHASAN}

Bagian awal artikel ini menjelaskan bagaimana produk media pembelajaran IPS berbasis android yang memiliki 5 fitur yang terdiri dari, fitur petunjuk teknis, fitur KI dan KD, fitur materi, fitur diskusi, dan fitur tes dihasilkan (Gambar 1).

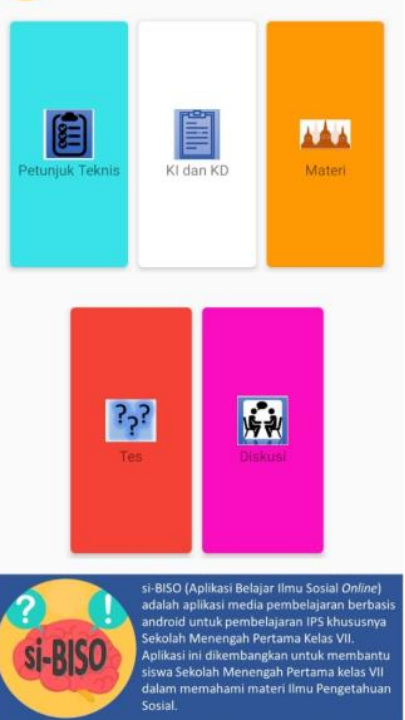

Gambar 1. Hasil Pengembangan Media Pembelajaran IPS Berbasis Android

Pengguna dapat menggunakan media pembelajaran IPS berbasis android dengan cara online. Pada fitur materi disajikan rangkuman materi yang dapat membantu siswa/pengguna dalam memahami materi lebih singkat dan jelas, selain itu terdapat video yang dapat diputar berulang kali. Pada fitur diskusi pengguna dapat menjawab pertanyaan yang telah tersedia. Tahap analisis dimulai dengan melakukan analisis kurikulum dan materi disesuaikan dengan Standar Kompetensi 
dan Kompetensi Inti mata pelajaran IPS Sekolah Menengah Pertama. Selanjutnya analisis kebutuhan yang bertujuan untuk memperoleh informasi berkaitan dengan media yang akan dikembangkan sehingga sesuai dengan kebutuhan siswa (Ahmadi et al., 2017). Analisis kebutuhan pengguna dilakukan untuk mengetahui jenis sistem operasi dan spesifikasi smartphone di lapangan, dan selanjutnya analisis isi program. Informasi yang telah diperoleh dari lapangan digunakan untuk menyesuaikan isi program pada media pembelajaran. Analisis tersebut dilakukan untuk dapat menciptakan media pembelajaran yang sesuai dan membawa dampak positif bagi pengguna, sesuai pendapat Tafonao, (2018); Widiastika et al., (2020) bahwa media pembelajaran yang baik dapat meningkatkan kualitas belajar yang efektif dan menciptakan suasana menyenangkan bagi siswa. Hasil dari tahap analisis menjadi dasar dari rancangan bagaimana data dan navigasi, dan user interface. Rancangan awal juga mempertimbangkan kemudahan pengguna dalam menjalankan aplikasi, desain warna yang menarik, konten materi yang dapat diperbaharui secara berkesinambungan.

\section{Tabel 4. Hasil Validasi Ahli Materi}

\begin{tabular}{|c|c|c|c|c|c|}
\hline \multirow{2}{*}{ No. } & \multirow{2}{*}{ Komponen yang Dinilai } & \multicolumn{2}{|c|}{ Validasi ke-1 } & \multicolumn{2}{|c|}{ Validasi ke-2 } \\
\hline & & $\sum \mathbf{x}$ & Kriteria & $\sum \mathbf{x} \mathbf{K}$ & iteria \\
\hline 1 & $\begin{array}{l}\text { Kesesuaian materi dengan standar kompetensi dan } \\
\text { kompetensi dasar }\end{array}$ & 1 & $\begin{array}{l}\text { Sangat } \\
\text { Kurang }\end{array}$ & 2 & Cukup \\
\hline 2 & Kesesuaian materi dengan indikator & 2 & Cukup & 3 & Baik \\
\hline 3 & Kesesuaian materi dengan tujuan yang akan dicapai & 2 & Cukup & 3 & Baik \\
\hline 4 & $\begin{array}{l}\text { Cakupan dan kedalaman materi sesuai dengan tujuan } \\
\text { yang akan dicapai }\end{array}$ & 2 & Cukup & 3 & Baik \\
\hline 5 & $\begin{array}{l}\text { Ruang lingkup materi tergambar jelas dan mudah } \\
\text { diikuti }\end{array}$ & 2 & Cukup & 3 & Baik \\
\hline 6 & Kesesuaian sistematika penyajian materi & 1 & $\begin{array}{l}\text { Sangat } \\
\text { Kurang }\end{array}$ & 3 & Baik \\
\hline 7 & $\begin{array}{l}\text { Kesesuaian gambar dengan materi pada media } \\
\text { pembelajaran "si-BISO" }\end{array}$ & 2 & Cukup & 3 & Baik \\
\hline 8 & $\begin{array}{l}\text { Kebenaran isi materi yang disampaikan dalam media } \\
\text { pembelajaran "si-BISO" }\end{array}$ & 2 & Cukup & 2 & Cukup \\
\hline 9 & Kejelasan uraian materi & 2 & Cukup & 2 & Cukup \\
\hline 10 & $\begin{array}{l}\text { Kedalaman materi yang disajikan sesuai dengan isi } \\
\text { penjelasan }\end{array}$ & 2 & Cukup & 3 & Baik \\
\hline 11 & $\begin{array}{l}\text { Materi pada media pembelajaran "si-BISO" sesuai } \\
\text { dengan tingkat kemampuan siswa }\end{array}$ & 2 & Cukup & 2 & Cukup \\
\hline 12 & $\begin{array}{l}\text { Latihan soal pada media pembelajaran "si-BISO" } \\
\text { sesuai dengan materi }\end{array}$ & 3 & Baik & 2 & Cukup \\
\hline 13 & $\begin{array}{l}\text { Kejelasan petunjuk penugasan dengan pengerjaan } \\
\text { soal }\end{array}$ & 2 & Cukup & 2 & Cukup \\
\hline 14 & $\begin{array}{l}\text { Jenis soal pada media pembelajaran "si-BISO" sesuai } \\
\text { dengan indikator }\end{array}$ & 2 & Cukup & 2 & Cukup \\
\hline 15 & $\begin{array}{l}\text { Latihan soal pada media pembelajaran "si-BISO" } \\
\text { untuk mengukur pemahaman siswa pada materi }\end{array}$ & 3 & Baik & 2 & Cukup \\
\hline & Jumlah & 30 & Kurang & 37 & Layak \\
\hline
\end{tabular}

Pada Tabel 4 diatas adalah Hasil dari rancangan divalidasi oleh ahli materi, ahli bahasa, dan ahli media. Validasi menunjukkan sejauh mana suatu alat ukur mampu mengukur apa yang akan di ukur (Mustofa \& Supriyoko, 2017). Validasi dilakukan agar media pembelajaran IPS berbasis android memiliki kualitas yang layak sehingga dapat digunakan sebagai media pembelajaran. Aspek pertama untuk 
menilai kualitas produk suatu media pembelajaran adalah aspek validitas materinya (Haviz, 2016).

Hasil produk pertama masih kurang layak dalam aspek materi karena paparan materi masih belum dilengkapi dengan contoh kontekstual. Dari hasil perbaikan produk, kelayakan materi pembelajaran diperoleh dari hasil penilaian materi seperti, kesesuaian materi dengan indikator tujuan, ruang lingkup materi yang jelas, cakupan dan kedalaman materi dengan tujuan yang akan dicapai. Dari validasi tersebut diperoleh hasil $61,7 \%$ yang tergolong dalam kategori layak untuk digunakan sebagai media pembelajaran (Arikunto, 2013). Konten yang sudah disusun kemudian divalidasi kelayakan bahasa guna mengukur tingkat keterbacaan naskah produk (Tabel 5).

\section{Tabel 5. Hasil Validasi Ahli Bahasa}

\begin{tabular}{|c|c|c|c|}
\hline \multirow{2}{*}{ No. } & \multirow{2}{*}{ Komponen yang Dinilai } & \multicolumn{2}{|c|}{ Validasi } \\
\hline & & $\sum \mathrm{x}$ & Kriteria \\
\hline 1. & Menggunakan kaidah bahasa yang baik dan benar & 3 & Baik \\
\hline 2. & $\begin{array}{l}\text { Menggunakan istilah umum atau lokal yang sesuai dengan pokok } \\
\text { bahasan }\end{array}$ & 2 & Cukup \\
\hline 3. & $\begin{array}{l}\text { Bahasa yang digunakan lugas dan mudah dipahami oleh peserta } \\
\text { didik }\end{array}$ & 3 & Baik \\
\hline 4. & Menggunakan bahasa yang komunikatif dan informatif & 3 & Baik \\
\hline 5. & $\begin{array}{l}\text { Ketepatan penggunaan istilah atau bahasa lokal dalam } \\
\text { menguraikan materi }\end{array}$ & 2 & Cukup \\
\hline 6. & $\begin{array}{l}\text { Kalimat yang digunakan dapat menyampaikan isi materi atau } \\
\text { informasi dengan baik }\end{array}$ & 3 & Baik \\
\hline 7. & Kalimat yang digunakan sederhana dan sesuai dengan sasaran. & 3 & Baik \\
\hline 8. & Ketepatan ejaan & 3 & Baik \\
\hline 9. & Konsistensi penggunaan istilah & 3 & Cukup \\
\hline \multirow[t]{2}{*}{10.} & Konsistensi penggunaan tanda baca dan simbol & 3 & Baik \\
\hline & Jumlah & 28 & Layak \\
\hline
\end{tabular}

Aspek yang dinilai pada validasi bahasa yaitu penggunaan bahasa, ketepatan penulisan tanda baca, ketepatan istilah asing dan ejaan yang memperoleh kesimpulan layak. Kelayakan validasi bahasa terlihat dari hasil akhir sebesar 70\% yang tergolong dalam kategori layak untuk dijadikan sebagai media pembelajaran (Arikunto, 2013). Tahap akhir dari validasi adalah aspek teknis dalam produk yang dikomentari dari ahli media komunikasi (Tabel 6).

Tabel 6. Hasil Validasi Ahli Media

\begin{tabular}{|c|c|c|c|c|c|}
\hline \multirow{2}{*}{ No. } & \multirow{2}{*}{ Komponen yang Dinilai } & \multicolumn{2}{|c|}{ Validasi ke-1 } & \multicolumn{2}{|c|}{ Validasi ke-2 } \\
\hline & & $\sum \mathbf{x}$ & Kriteria & $\sum \mathbf{x}$ & Kriteria \\
\hline 1. & $\begin{array}{l}\text { Kesesuaian warna tampilan dan } \\
\text { background }\end{array}$ & 2 & Cukup & 3 & Baik \\
\hline 2. & $\begin{array}{l}\text { Warna dan unsur tata letak harmonis dan } \\
\text { memperjelas fungsi }\end{array}$ & 2 & Cukup & 3 & Baik \\
\hline 3. & $\begin{array}{l}\text { Ukuran font pada media pembelajaran } \\
\text { "si-BISO" sesuai }\end{array}$ & 3 & Baik & 4 & Sangat Baik \\
\hline 4. & Penyajian gambar jelas dan menarik & 2 & Cukup & 3 & Baik \\
\hline 5. & Penyajian video jelas dan menarik & 3 & Baik & 4 & Sangat Baik \\
\hline 6. & Tampilan gambar pada video jelas & 3 & Baik & 4 & Sangat Baik \\
\hline 7. & $\begin{array}{l}\text { Audio pada media pembelajaran "si- } \\
\text { BISO" jelas untuk didengar }\end{array}$ & 3 & Baik & 4 & Sangat Baik \\
\hline 8. & $\begin{array}{l}\text { Penyajian video dan gambar sesuai } \\
\text { dengan materi }\end{array}$ & 3 & Baik & 4 & Sangat Baik \\
\hline
\end{tabular}




\begin{tabular}{|c|c|c|c|c|c|}
\hline \multirow{2}{*}{ No. } & \multirow{2}{*}{ Komponen yang Dinilai } & \multicolumn{2}{|c|}{ Validasi ke-1 } & \multicolumn{2}{|c|}{ Validasi ke-2 } \\
\hline & & $\sum \mathbf{x}$ & Kriteria & $\sum \mathbf{x}$ & Kriteria \\
\hline 9. & Kesesuaian keterangan dengan gambar & 2 & Cukup & 3 & Baik \\
\hline 10. & Kesesuaian keterangan dengan video & 3 & Baik & 4 & Sangat Baik \\
\hline 11. & $\begin{array}{l}\text { Kejelasan teks pada media pembelajaran } \\
\text { "si-BISO" untuk dibaca }\end{array}$ & 4 & Sangat Baik & 4 & Sangat Baik \\
\hline 12. & $\begin{array}{l}\text { Kemudahan dalam } \\
\text { pemeliharaan/perawatan media } \\
\text { pembelajaran "si-BISO" }\end{array}$ & 3 & Baik & 4 & Sangat Baik \\
\hline 13. & $\begin{array}{l}\text { Kemudahan dalam pengoperasian media } \\
\text { pembelajaran "si-BISO" }\end{array}$ & 2 & Cukup & 3 & Baik \\
\hline 14. & $\begin{array}{l}\text { Kesederhanaan dalam pengoperasian } \\
\text { media pembelajaran "si-BISO" }\end{array}$ & 2 & Cukup & 3 & Baik \\
\hline 15. & $\begin{array}{l}\text { Keefektifan media pembelajaran "si- } \\
\text { BISO" dalam penggunaannya }\end{array}$ & 3 & Baik & 4 & Sangat Baik \\
\hline 16. & $\begin{array}{l}\text { Kemudahan dalam penggunaan media } \\
\text { pembelajaran "si-BISO" oleh siswa di } \\
\text { mana pun dan kapan pun }\end{array}$ & 1 & Kurang & 2 & Cukup \\
\hline 17. & $\begin{array}{l}\text { Kesesuaian program dengan kemampuan } \\
\text { smartphone saat ini }\end{array}$ & 2 & Cukup & 3 & Baik \\
\hline 18. & $\begin{array}{l}\text { Keseluruhan program tersaji secara } \\
\text { sistematis dan padat }\end{array}$ & 3 & Baik & 4 & Sangat Baik \\
\hline 19. & $\begin{array}{l}\text { Media mampu mendorong siswa untuk } \\
\text { berperan aktif dalam proses pembelajaran }\end{array}$ & 4 & Sangat Baik & 4 & Sangat Baik \\
\hline & Jumlah & 50 & Layak & 67 & Sangat Layak \\
\hline
\end{tabular}

Setelah konten materi sudah siap, tahap akhir dari pengembangan merupakan penataan konten dalam produk yang disusun. Hasil penyusunan pertama dalam prototipe produk, ahli media komunikasi memberikan komentar bahwa sajian sudah layak namun guna mempermudah pengguna perlu ada peningkatan pada beberapa aspek seperti manual user dan tombol navigasi. Kesimpulan hasil validasi media bahwa media pembelajaran IPS berbasis android sangat layak. Kelayakan media diperoleh dari validasi ahli media yang menunjukkan hasil akhir $88,2 \%$ yang masuk pada kategori sangat layak untuk digunakan sebagai media pembelajaran (Arikunto, 2013).

Kualitas pengembangan media pembelajaran IPS berbasis android dilihat dari ketiga aspek penilaian tersebut diketahui bahwa media layak/valid, sesuai pendapat Arikunto (2013) bahwa sebuah media pembelajaran dikatakan valid apabila hasilnya sesuai dengan kriteria, dalam arti hasil validasi memiliki kesamaan hasil akhir dengan kriteria yang telah ditentukan sebelumnya. Sehingga dapat disimpulkan bahwa pengembangan media pembelajaran IPS berbasis android sudah sesuai dengan kriteria kelayakan media pembelajaran, bahwa media pembelajaran IPS berbasis android layak (Arikunto, 2013) dan dapat digunakan dalam proses pembelajaran IPS di SMP/MTs.

Tahap akhir dari pengembangan produk adalah uji coba pada calon pengguna. Subjek yang digunakan adalah siswa kelas VII A SMP Shalahuddin Malang dengan difasilitatori oleh guru IPS. Setelah menggunakan media pembelajaran tersebut pengguna diminta memberikan penilaian terkait kepraktisan media pembelajaran IPS berbasis android (Tabel 7). 
Tabel 7. Kepraktisan Media Pembelajaran oleh Praktisi Pendidikan

\begin{tabular}{lll}
\hline No. Komponen yang Dinilai & $\sum \mathbf{x}$ & Kriteria \\
\hline Aspek Media & & \\
\hline 1. $\quad \begin{array}{l}\text { Warna dan tampilan background pada media pembelajaran } \\
\text { "si-BISO" menarik }\end{array}$ & 4 & Sangat Praktis \\
2. $\quad \begin{array}{l}\text { Video dan gambar yang disajikan pada media pembelajaran } \\
\text { "si-BISO" sesuai dengan materi }\end{array}$ & 4 & Sangat Praktis \\
3. $\quad$ Media pembelajaran "si-BISO" mudah dioperasikan & 4 & Sangat Praktis \\
4. $\quad$ Media pembelajaran "si-BISO" efektif dalam penggunaannya & 4 & Sangat Praktis \\
5. $\quad \begin{array}{l}\text { Media pembelajaran "si-BISO" mempermudah siswa untuk } \\
\text { belajar kapan pun dan dimana pun }\end{array}$ & 4 & Sangat Praktis
\end{tabular}

\begin{tabular}{|c|c|c|c|}
\hline \multicolumn{4}{|c|}{ Aspek Materi } \\
\hline 6. & Penyajian materi yang runtut & 4 & Sangat Praktis \\
\hline 7. & $\begin{array}{l}\text { Materi pada media pembelajaran "si-BISO" sesuai dengan } \\
\text { Kompetensi Dasar }\end{array}$ & 4 & Sangat Praktis \\
\hline 8. & $\begin{array}{l}\text { Materi pada media pembelajaran "si-BISO" sesuai dengan } \\
\text { Indikator }\end{array}$ & 4 & Sangat Praktis \\
\hline 9. & $\begin{array}{l}\text { Materi pada media pembelajaran "si-BISO" sesuai dengan } \\
\text { tujuan pembelajaran }\end{array}$ & 4 & Sangat Praktis \\
\hline 10. & $\begin{array}{l}\text { Sistematika penyajian materi pada media pembelajaran "si- } \\
\text { BISO" sesuai }\end{array}$ & 4 & Sangat Praktis \\
\hline 11. & $\begin{array}{l}\text { Materi pada media pembelajaran "si-BISO" sesuai dengan } \\
\text { tingkat kemampuan siswa }\end{array}$ & 4 & Sangat Praktis \\
\hline \multirow[t]{2}{*}{12.} & $\begin{array}{l}\text { Jenis soal pada media pembelajaran "si-BISO" sesuai dengan } \\
\text { indikator pembelajaran }\end{array}$ & 4 & Sangat Praktis \\
\hline & Jumlah & 48 & Sangat Praktis \\
\hline
\end{tabular}

Penilaian kepraktisan dari seorang praktisi pendidikan mendapatkan persetase $100 \%$ sehingga dapat disimpulkan bahwa media pembelajaran IPS berbasis android sangat praktis untuk digunakan dalam proses pembelajaran IPS Terpadu (Akbar, et al., 2011). Hasil ini menunjukkan bahwa praktisi dalam hal ini adalah guru mata pelajaran IPS mudah menggunakan produk yang dihasilkan dan bisa memfasilitasi pencapaian tujuan pembelajaran yang direncanakan. Uji coba berikutnya juga dilakukan kepada calon pengguna, peserta didik (Tabel 8).

Tabel 8. Kepraktisan Media Pembelajaran oleh Peserta Didik

\begin{tabular}{|c|c|c|c|}
\hline No. & Komponen yang Dinilai & $\sum \mathrm{x}$ & Kriteria \\
\hline 1. & Media pembelajaran si-BISO meningkatkan minat belajar & 101 & Praktis \\
\hline 2. & Media pembelajaran si-BISO menarik untuk digunakan & 104 & Sangat Praktis \\
\hline 3. & Media pembelajaran si-BISO mudah untuk digunakan & 104 & Sangat Praktis \\
\hline 4. & Media pembelajaran si-BISO menyenangkan & 105 & Sangat Praktis \\
\hline 5. & $\begin{array}{l}\text { Media pembelajaran si-BISO membantu meningkatkan } \\
\text { pemahaman siswa terhadap materi pembelajaran }\end{array}$ & 97 & Praktis \\
\hline 6. & $\begin{array}{l}\text { Soal latihan atau tes pada media pembelajaran si-BISO } \\
\text { sangat menyenangkan }\end{array}$ & 102 & Praktis \\
\hline 7. & $\begin{array}{l}\text { Diskusi pada media pembelajaran si-BISO sangat } \\
\text { menyenangkan }\end{array}$ & 99 & Praktis \\
\hline 8. & $\begin{array}{l}\text { Penggunaan bahasa yang baik pada media pembelajaran si- } \\
\text { BISO }\end{array}$ & 109 & Sangat Praktis \\
\hline 9. & Media pembelajaran si-BISO praktis digunakan & 104 & Sangat Praktis \\
\hline \multirow[t]{2}{*}{10.} & $\begin{array}{l}\text { Media pembelajaran si-BISO sangat diperlukan dalam } \\
\text { proses pembelajaran }\end{array}$ & 102 & Praktis \\
\hline & Jumlah & 1027 & Sangat Praktis \\
\hline
\end{tabular}


Penilaian dari siswa memiliki persentase $80,2 \%$ yang tergolong dalam kategori sangat praktis (Akbar, et al., 2011). Berdasarkan kedua respons dari praktisi pendidikan dan siswa bahwa media pembelajaran IPS berbasis android sangat praktis digunakan dalam proses pembelajaran IPS Terpadu. Sesuai dengan pendapat Dwijayani (2017) bahwa kepraktisan media pembelajaran tergambar dari pengaplikasian media pembelajaran yang memberikan manfaat yang baik bagi pengguna, terlihat dari respons pengguna bahwa media pembelajaran IPS berbasis android memberikan manfaat sehingga terlihat perolehan nilai kepraktisan yang tinggi. Media pembelajaran yang praktis dapat mempermudah siswa dalam belajar sehingga meningkatkan ketertarikan siswa terhadap proses pembelajaran. Media pembelajaran IPS berbasis android dinilai praktis karena siswa merasa nyaman dan senang dalam belajar (Alhafidz et al., 2017).

Pada tahap implementasi media pembelajaran IPS berbasis android diketahui bahwa media pembelajaran efektif. Media pembelajaran dikatakan efektif apabila setiap siswa tuntas dalam belajar, mempengaruhi keaktifan dan keterampilan proses terhadap prestasi siswa (Bire, Geradus, \& Bire, 2014). Keefektifan media pembelajaran terukur dari keberhasilan siswa dalam memahami materi pembelajaran yang diukur melalui tes (Salamah, 2017). Efektivitas media pembelajaran diukur melalui tes yang telah tersedia pada aplikasi dengan membandingkan jumlah ketuntasan siswa dengan jumlah keseluruhan siswa. Persentase siswa yang memiliki nilai di atas KKM dapat terlihat pada (Gambar 2).

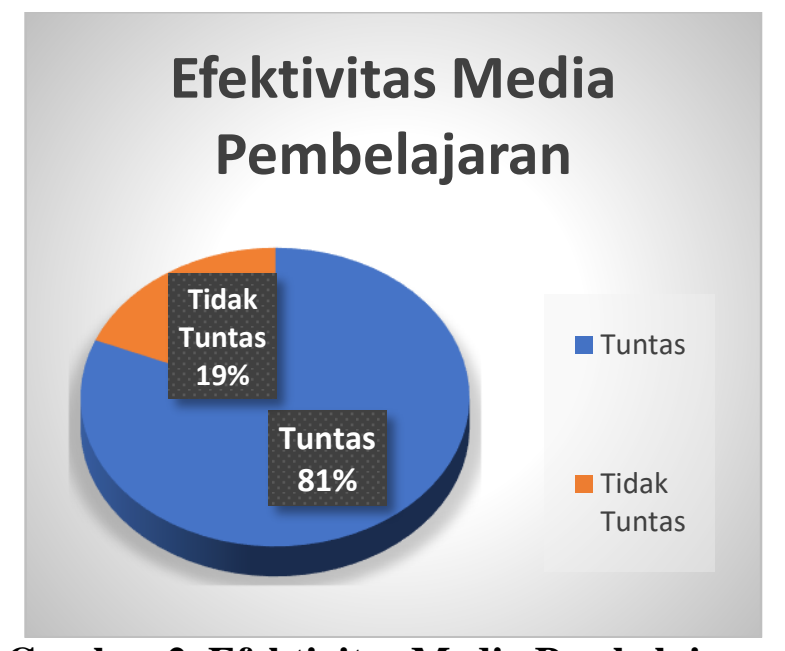

\section{Gambar 2. Efektivitas Media Pembelajaran}

Efektivitas media pembelajaran IPS berbasis android seperti pada gambar 2 menyimpulkan bahwa $81 \%$ siswa dapat meraih nilai di atas KKM, sehingga media dapat dikatakan efektif untuk digunakan siswa pada proses pembelajaran IPS. Sesuai yang dikemukakan oleh Ariyanto (2011) bahwa suatu pembelajaran dikatakan efektif jika memenuhi ketercapaian pengukuran ketuntasan belajar. Keberhasilan siswa dalam memahami materi pembelajaran dengan menggunakan smartphone berbasis android ini dipengaruhi oleh faktor-faktor seperti, kemudahan siswa dalam belajar atau mengulang pembelajaran karena penggunaan smartphone lebih banyak daripada komputer dan lebih mudah dioperasikan, memberikan kesempatan belajar yang mendalam bagi siswa karena dapat mengembangkan pembelajaran penelusuran informasi melalui internet (Ismanto et al., 2017) dan memberikan kesempatan belajar sendiri serta beraktivitas seluas-luas dengan 
mengembangkan potensi yang dimiliki dengan baik. Faktor-faktor tersebut yang mempengaruhi pemahaman siswa terhadap materi IPS meningkat.

Media pembelajaran IPS berbasis android dapat mempermudah guru dan siswa dalam proses pembelajaran jarak jauh. Siswa dapat mempelajari materi, berdiskusi, dan mengerjakan tes dalam satu aplikasi dengan menggunakan smartphone. Walaupun fungsi media pembelajaran IPS berbasis android sebagai alat bantu, akan tetapi memiliki peran tersendiri, karena dalam perkembangan teknologi seperti ini memungkinkan siswa dalam belajar di mana pun dan kapan pun dengan memanfaatkan hasil teknologi (Sutiasih \& Saputri, 2019). Media pembelajaran ini dapat dikembangkan lebih lanjut oleh peneliti lain dengan memanfaatkan teknologi virtual reality. Untuk memudahkan siswa dalam memahami materi pembelajaran, selain menggunakan video dan gambar seperti pada media pembelajaran "si-BISO", peneliti selanjutnya dapat menambahkan virtual reality sehingga gambar dan objek pembelajaran dapat tergambar dengan jelas.

\section{SIMPULAN}

Berdasarkan uraian dan temuan yang diperoleh dalam penelitian dan pengembangan ini dikemukakan kesimpulan yaitu: Pengembangan media pembelajaran IPS berbasis android dinyatakan valid. Hasil implementasi media pembelajaran IPS berbasis android bahwa kepraktisan media terbukti sangat praktis untuk digunakan dan efektivitas terbukti efektif terlihat dari dampak positif pengguna media, keberhasilan siswa menyelesaikan tes dengan nilai rata-rata di atas KKM yang telah ditentukan sekolah. Produk media pembelajaran IPS berbasis android direkomendasikan untuk: 1) siswa, dengan memanfaatkan media pembelajaran IPS berbasis android siswa dapat dengan mudah memahami materi pembelajaran, 2) guru IPS SPM/MTs, dapat memanfaatkan produk media sebagai pilihan media pembelajaran baru dengan memanfaatkan teknologi

\section{DAFTAR PUSTAKA}

Afandi, R. (2015). Pengembangan Media Pembelajaran Permainan Ular Tangga Untuk Meningkatkan Motivasi Belajar Siswa dan Hasil Belajar IPS di Sekolah Dasar. JINoP (Jurnal Inovasi Pembelajaran), 1(1), 77. https://doi.org/10.22219/jinop.v1i1.2450

Ahmadi, F., Sutaryono, S., Witanto, Y., \& Ratnaningrum, I. (2017). Pengembangan media edukasi "Multimedia Indonesian Culture"(MIC) sebagai penguatan pendidikan karakter siswa Sekolah Dasar. Jurnal Penelitian Pendidikan, 34(2), 127-136.

Akbar, Sa'dun \& Sriwiyana, H. (2011). Pengembangan Kurikulum dan Pembelajaran Ilmu Pengetahuan Sosial (IPS). Yogyakarta: Cipta Media.

Alhafidz, M. R., \& Haryono, A. (2017). Pengembangan Mobile Learning Berbasis Android Sebagai Media Pembelajaran Ekonomi. Jurnal Pendidkan Ekonomi, 11, 2018.

Arikunto, \& Suharsimi. (2013). Prosedur Penelitian Suatu Pendekatan Praktik. Jakarta: Rineka Cipta.

Ariyanto, L. (2011). Pengembangan Perangkat Pembelajaran Matematika Model Berjangkar (Anchored Instruction) Materi Luas Kubus dan Balok Kelas VIII. Aksioma: Jurnal Matematika Dan Pendidikan Matematika UPGRIS Semarang, 2(2). 
Badlisyah, T., \& Maghfirah, M. (2017). Penggunaan macromedia flash pada materi larutan penyangga terhadap hasil belajar siswa kelas XI MAN Darussalam. Lantanida Journal, 5(1), 42. https://doi.org/10.22373/lj.v5i1.2058

Bire, Geradus, \& Bire, J. (2014). Effects of Visual, Auditorial, and Kinesthetic Learning Styles on Student Learning Achievement. Pengaruh Gaya Belajar Visual, Auditorial, Dan Kinestetik Terhadap Prestasi Belajar Siswa, 44(2).

Cahyani, I. (2014). Pentingnya Mengenali Gaya Belajar dalam Kegiatan Pembelajaran.

Dewi, G. P. F. (2012). Pengembangan game edukasi pengenalan nama hewan dalam bahasa inggris sebagai media pembelajaran siswa sd berbasis macromedia flash [Universitas Negeri Yogyakarta]. In Universitas Negeri Yogyakarta. https://core.ac.uk/download/pdf/11066087.pdf

Dwijayani, N. M. (2017). Pengembangan Media Pembelajaran ICARE. Kreano, Jurnal Matematika Kreatif-Inovatif, $8(2), \quad 126-132$. https://doi.org/10.15294/kreano.v8i2.10014

Haviz, M. (2016). Research and Development; Penelitian Di Bidang Kependidikan Yang Inovatif, Produktif Dan Bermakna. Ta'dib, 16(1). https://doi.org/10.31958/jt.v16i1.235

Hayati, S., Budi, A. S., \& Handoko, E. (2015). Pengembangan media pembelajaran flipbook fisika untuk meningkatkan hasil belajar peserta didik. Prosiding Seminar Nasional Fisika (e-Jurnal) SNF2015, 4, 49-61. http://journal.unj.ac.id/unj/index.php/prosidingsnf/article/view/4810/3587

Ismanto, E., Novalia, M., \& Herlandy, P. B. (2017). Pemanfaatan Smartphone Android Sebagai Media Pembelajaran Bagi Guru Sma Negeri 2 Kota Pekanbaru. Jurnal Pengabdian UntukMu NegeRI, 1(1), 42-47. https://doi.org/10.37859/jpumri.v1i1.33

Kurniawan, B., Idris, Purnomo, A., Wiradimadja, A., \& Sukamto. (2019). Using broadcasting learning design to enhance student's experiential skill. International Journal of Emerging Technologies in Learning, 14(16), 172180. https://doi.org/10.3991/ijet.v14i16.10652

Maknuni, J., \& Artikel, I. (2020). Indonesian Education Administration and Leadership Journal (IDEAL) Pengaruh Media Belajar Smartphone Terhadap Belajar Siswa Di Era Pandemi Covid-19 (The Influence of Smartphone Learning Media on Student Learning in The Era Pandemi Covid-19). 02, 94106.

Mustofa, R. A., \& Supriyoko, S. (2017). Pengembangan instrumen pengukuran nilai kemandirian terkait mata pelajaran matematika (Studi empirik di SMA Negeri 1 Sleman). Wiyata Dharma: Jurnal Penelitian Dan Evaluasi Pendidikan, 5(1), 70-75.

Nurfajriati, D. (1981). Faktor-faktor Kesulitan Belajar Mata Pelajaran Ilmu Pengetahuan Sosial Pada Siswa Kelas 7 di SMPN 2 Mlati Tahun Pelajaran 2017/2018. Journal of Chemical Information and Modeling, 53(9), 16891699.

Kurniawan, M. (2017). Analisis Karakter Media Pembelajaran Berdasarkan Gaya Belajar Peserta Didik. JINoP (Jurnal Inovasi Pembelajaran), 3(1), 491. https://doi.org/10.22219/jinop.v3i1.4319

Rustandi, A., Asyril, A., \& Hikma, N. (2020). Pengembangan media pembelajaran berbasis android pada mata pelajaran simulasi dan komunikasi digital kelas $\mathrm{x}$ sekolah menengah kejuruan teknologi informasi airlangga tahun ajaran 
2020/2021. MEDIA BINA ILMIAH, 15(2), 4085-4092.

Salamah, E. R. (2017). Pengembangan Media Pembelajaran Berbasis Audio Visual Tokoh-Tokoh Kemerdekaan Indonesia. Premiere Educandum: Jurnal Pendidikan Dasar Dan Pembelajaran, 7(01), 9. https://doi.org/10.25273/pe.v7i01.1251

Sugiyono. (2017). Metode Penelitian Pendidikan Pendekatan Kuantitatif, Kualitatif, dan $R \& D$. Bandung: Alfabeta.

Surahman, E., \& Mukminan, M. (2017). Peran guru IPS sebagai pendidik dan pengajar dalam meningkatkan sikap sosial dan tanggung jawab sosial siswa SMP. Harmoni Sosial: Jurnal Pendidikan IPS, 4(1), 1-13. https://doi.org/10.21831/hsjpi.v4i1.8660

Sutiasih, A. D., \& Saputri, R. P. (2019). Pengembangan mobile learning berbasis android sebagai media pembelajaran organisasi arsitektur komputer. Jurnal Inovasi Teknologi Pendidikan, 6(2), 137-147. https://doi.org/10.21831/jitp.v6i2.27772

Tafonao, T. (2018). Peranan media pembelajaran dalam meningkatkan minat belajar mahasiswa. Jurnal Komunikasi Pendidikan, 2(2), 103. https://doi.org/10.32585/jkp.v2i2.113

Verawati; Enny Comalasari. (2019). Pemanfaatan Android Dalam Dunia Pendidikan. Prosiding Seminar Nasional Pendidikan Program Pascasarjana Universitas Pgri Palembang 03 Mei 2019, 2, 617-627.

Wahyuningtyas, N., \& Rosita, F. A. D. (2019). Pengembangan Multimedia Interaktif Berbasis Android Pada Materi Kehidupan Sosial Masyarakat Indonesia. Sejarah Dan Budaya Jurnal Sejarah Budaya Dan Pengajarannya, 13(1), 34-41. https://doi.org/10.17977/um020v13i12019p034

Widayanti, F. D. (2013). Pentingnya Mengetahui Gaya Belajar Siswa Dalam Kegiatan Pembelajaran Di Kelas. Erudio Journal of Educational Innovation, 2(1). https://doi.org/10.18551/erudio.2-1.2

Widiastika, M. A., Hendracipta, N., \& Syachruroji, A. (2020). Pengembangan Media Pembelajaran Mobile Learning Berbasis Android pada Konsep Sistem Peredaran Darah di Sekolah Dasar. Jurnal Basicedu, 3(2), 524-532.

Yuniati, Y., \& Ratmanto, T. (2017). Prosiding SNaPP2017 Sosial, Ekonomi, dan Humaniora. Smarthphone Sebagai Media Pembelajaran Student Centered Learning, 764. 